\title{
Framing globalization and constructing the world: cultural and political approaches
}

\author{
Bernard Debarbieux, Juliet J. Fall, Frédéric Giraut, \\ Estelle Sohier, Jean-François Staszak, Genève
}

\section{Introduction}

In most of contemporary geographical literature, globalization is straightforwardly conceived as the growing importance of the global level in the organization of geographical flux, processes and actions. It is said to be either the triumph of a single, overarching scale-level, or, in a more subtle way, the «rescaling» of geographical reality, in which each scale-level (e.g. local, sub-national, national, regional) is re-structured along with the rise of a global one. A large part of the existing papers on globalization, especially in Englishspeaking geography, has emerged from political geography and adopted a critical point of view. In most of papers devoted to «the politics of scale», it is said that post-industrial capitalism, fuelled by neo-liberal ideologies, is the main driver of globalization. However, significant contributions have been published that deal specifically with cultural globalization (related in particular to migrations and circulation of cultural models) or environmental governance.

Meanwhile, cognitive approaches to globalization e.g. globalization as a state of mind, as a way of framing reality, as a type of awareness - have been quite rare in geography, contrary to what occurred in sociology (e.g. with Ulrich Beck), anthropology (e.g. with Arjun Appadurai) or in political science. Though working on various topics and according to various theories and epistemological basis, the researchers of the Department of Geography of the University of Geneva who author this collective paper all hold an interest in cognitive approaches. Their overlapping fields of interest share a specific attention to techniques and products of representation or figuration (e.g. maps, GIS, pictures) through which a spatial arrangement or a scale-level is promoted or justified by social actors, including scientists. Together, we are interested in the extent to which globalization is, amongst other things, a cognitive process that relies on the emergence of new key figures and representations, as well as new meanings and new forms of circulation that are associated with them. In this paper, we explore the connections between different fields of our work through the joint lenses of scaling and framing. We have found this a fertile path to follow in helping us link up our different fields of geographical research spanning cultural and politi- cal geographies, providing pathways for constructing a theoretically-aware, critical geography, beyond the usual sub-discipline divisions that can be found in much so-called international geography. Here, we explore this approach theoretically, before applying it to three examples currently considered within existing research projects: the globalization and rescaling of environmental discourse, the circulation of images of otherness and the process of othering; and the globalization of environmental and cultural issues within mountain areas. This of course does not reflect all the research activity of our department, but gives some idea of the sort of theoretical approaches we adopt for a variety of research objects.

\section{Framing and scaling on a global level}

The concept of frame has been used in academic literature since the famous book by ERWIN GoFFMAN (1974). The sociologist defined frames as «schemata of interpretation» which «enable individuals to locate, perceive, identify, and label occurrences within their life space at large» (GoFFMAN 1974: 21). Used that way, the concept of frame refers to a social mode of shaping the external world, where cognition plays a decisive role. The concept was later reshaped in political sociology and political science discourse, especially following BENFORD and SNOw who saw framing as a way to

\footnotetext{
«assign meaning to and interpret relevant events and conditions in ways that are intended to mobilize potential adherents and constituents, to garner bystander support, and to demobilize antagonists» (SNOw \& BENFord 1988: 198).
}

Such a cognitive approach led to two decades of work seeking to explain a wide set of social practices: collective action, public policies (FAURE et al. 1997) and environmental controversies (such as CALLON et al. 2001). It should be noted that among the scientists who entered this field of research, some left aside the concept of frame/framing and promoted alternatives: ideology, paradigm or «référentiels» (as used by a specific French school of political scientists). Due to limited space this question of naming and labelling will not be addressed here.

The huge interest for the concept of frame cannot be isolated from the work of philosophers who, while they never referred to that word as a major concept, underlined the importance of «discursive formation» 
(Michel Foucault) and narratives (Paul Ricœur) in the identification of relevant objects of knowledge, the motivation or justification of action or the making of modern identities.

In geography, the concept of framing and, more generally, cognitive approaches developed specificities compared to what occurred in other social sciences, in particular related to the concept of scale. Thanks to more than a decade of critical and epistemological work on this concept, it became more and more common in human geography to define scale as socially constructed (MARSTON 2000), and to relate it to frames. Scale came to be seen as a product or a modality of a framing process. Both concepts were to become so closely combined in constructivist approaches that LARSEN could write that

«environmental concerns in important respects are framed and reframed as spatial objects for politics through processes of scaling» (LARSEN 2008: 2000).

KURTZ and MOore promoted the phrase «scale frames» defined as

«discursive practices that construct meaningful (and actionable) linkages between the scale at which a social problem is experienced and the scale(s) at which it could be politically addressed or resolved» (KURTZ 2003: 894).

\section{Moore stated that}

«framing the spatial and temporal context is central to the ultimate success of any political project. Consequently, scale framing and contestations over scale frames is an important object of inquiry in the dynamics of scale politics» (Moore 2008: 218).

Scaling and framing could then become combined in critical approaches: «the politics of scale may often take the form of contending 〈framings»» (Delanay \& LEITNER 1997).

Of the other specificities of geographical analysis in terms of framing, probably the more influential has been the focus on the production and circulation of images, especially maps, in geographical analysis. It has been suggested that the spatiality of images produced along with spatial or territorial practices could be analyzed as a specific mode of framing, as an important if not decisive step in the «spatial framing» of an object (e.g. place, area, region) being planned, negotiated, contested, etc. The map, for example, operates as a frame, a window open on the represented reality, which makes a clear distinction between what is shown (in-frame) and what is left aside (off-frame). Such a visual framing is often part of the description of a real- ity, of the problem-setting undertaken by stakeholders, of planning, of controversies, etc. (see among a wide set of publications, Aberley 1993; Farinelli 2009; PiCKLes 2004). The same can be said for other kinds of images: pictures, animated fictions, documentaries, etc. These play a decisive role in the way individuals mentally shape their environment and organize their relative knowledge. It also plays a decisive role in scientific argumentation, in the making of controversies or participative processes. Thus, along with argumentative framing, «visual framing» (the production, use and circulation of iconic materials and visual artefacts) is an important mode or step in shaping reality, worldviews and institutional and collective action.

Based on this theoretical understanding, several research projects have been undertaken in the department of geography of Geneva, all questioning the nature of the global scale-level and the framing of social issues at this level, but focusing on different research subjects and topics.

\section{Example 1: the circulation of species and globalization of the environment}

The question of the circulation of living matter, plants, animals and pathogens in a world of accelerated longdistance exchanges is an object of attention of two research projects (Juliet Fall, Marion Ernwein). These exchanges are increasingly framed as a global problem of security within which species are required to establish their right to belong somewhere: indigenous species are, for instance, valued more than recent imports. Terms, such as invasive, exotic, non-native, non-indigenous and alien have been used to describe this global swarming of species: plants and animals seen as out-ofplace and out-of-control beyond their native habitats, categorised as dangerous and singled out for destruction (FALL 2011a, 2012). Countries that have ratified the Convention on Biological Diversity are required to set up national strategies to govern and control the circulation of non-native plants and animals defined as invasive, and to list such species on Black Lists (Article $8 \S \mathrm{h}$ ). Changing climates complicate the story, as it is recognised that many species need to move in order to survive, yet these changes in ecological assemblages are cast as the problem.

Any examination of the ways in which the question of invasive species is constituted, and how specific species are categorised both globally and nationally, has to take into account the particular techniques, data, artefacts and practices that are deployed in order to constitute the problem and subsequently - or rather simultaneously - enact particular governmental programmes to manage it. Framing is thus not only a rhe- 
torical trick: it is also a fundamentally material practice. Global, in this context is spatially uneven rather than uniform: the consequence of specific connections and encounters that work across and through difference (FALL 2011b).

Scaling up environmental policies to a global scale is not unproblematic in this case: plants defined as «globally invasive» inevitably come from somewhere, implying that any global attempts to control them have to take into account this question of geographical origin, and the very vitality and adaptability of the species in question. The question of scale of environmental governance is thus particularly intriguing here, as a simple cumulation of local scenarios into a global framework cannot make any sense. This rescaling of environmental policy and governance is thus intrinsically messy, context-dependent and fluid. Furthermore, because these tales tell of swarming, invading, foreign, and out-of-control natures, opportunistically playing on other social fears (FALl \& MATTHEY 2011), this often becomes a highly charged and emotional debate, creating new challenges for adapting governance structures to local contexts.

One starting point of this is the idea of biodiversity, a term that has durably modified not only how we think about nature and the environment, but also who is responsible for making and solving problems pertaining to it. The crucial role of conservation biology and biologists is well known and documented, centred on an accounting paradigm of numbers of individualised species, discernible on lists and in the dynamic assemblages of different species that are seen to paradoxically both reflect a carefully-evolved order and a capacity for change. Yet, perhaps curiously, it is the question of order and permanence that is particularly prevalent in the popular imagination, and that paradoxically receives the most attention. Thus, spatial disorder grounds the problem: unlike pollution or greenhouse gases that are a problem regardless of their location, invasive species are only a problem when they are growing in the wrong place. Ironically, in some cases, one particular species can be both globally threatened - and therefore on a Red List in one country - and designated as an invasive species - and therefore on a national Black List in another, marked out for eradication or at least control. This is therefore not a clear-cut story of global «goodies» and «baddies», as overlapping place-based identities are in constant tension.

In Switzerland, the creation of the collective category of invasive plants - and in a sense the collective framing of certain plants as invasive - as well as the subsequent legal instruments drafted to respond heavily relied on the presence of one specific plant growing in particular places. Ragweed (Ambrosia artemisiifolia), originally from North America, is a weedy plant that can create severe respiratory reactions in some people. At the same time, it has been quietly celebrated as a useful champion by certain botanists who have strategically used the increased political interest in threats to human health to raise the profile of invasive plant species as a pertinent collective category.

In helping to identify these problematic plants, the Federal Office for the Environment mandated the Secretariat of the Swiss Commission for Wild Plant Conservation (CPS) to draw up lists. The two permanent employees of this organisation were assisted by about 15 other people chosen to represent the diversity of floristic - and political - regions in the country, with specific emphasis on border areas, seen as key entry points for new species. This being Switzerland, where political sensitivities need balancing, the political and geographical selection of members was intrinsically political and geographical. The group included a Ticinese, two or three Swiss-Germans, a Genevois and others specifically chosen because they worked close to border areas. This focus on border areas is intriguing, yet it directly stems from the choice of the national scale as pertinent for recording biodiversity and listing species, and the assumption that threats come from «outside», i.e. beyond the national borders. These are almost considered given features of the landscape. For if we assume for the sake of argument that species are randomly spread across the world and are in some sort of gentle flux, yet are listed and counted by country, then surely zones of flux are inevitably going to be focussed on boundary areas, and central areas are going to be seen as having a more stable mix of species? New species of invasive plants and animals will be found at the edges of states, including zones of longdistance transport such as freight terminals. The global topologies of dispersal may be complex, through longdistance networks as well as across adjacent territories, but the concept of «edge» will always be defined in reference to the national scale at which biodiversity is counted. Thus the identification and framing of much of the question of invasive species relies paradoxically on the assumption of the state as a given (FALL 2010).

\section{Example 2: the circulation of images of others and the construction of exoticism}

Otherness became a geographical issue with the development of post-modern, post-colonial and queer analyses in the 1980's. Geographers have had to ask questions about the diversity of groups in terms of socio-discursive construction rather than in terms of supposed objectives of difference, as had been done until then (STASZAK 2009). Furthermore, exoticisa- 


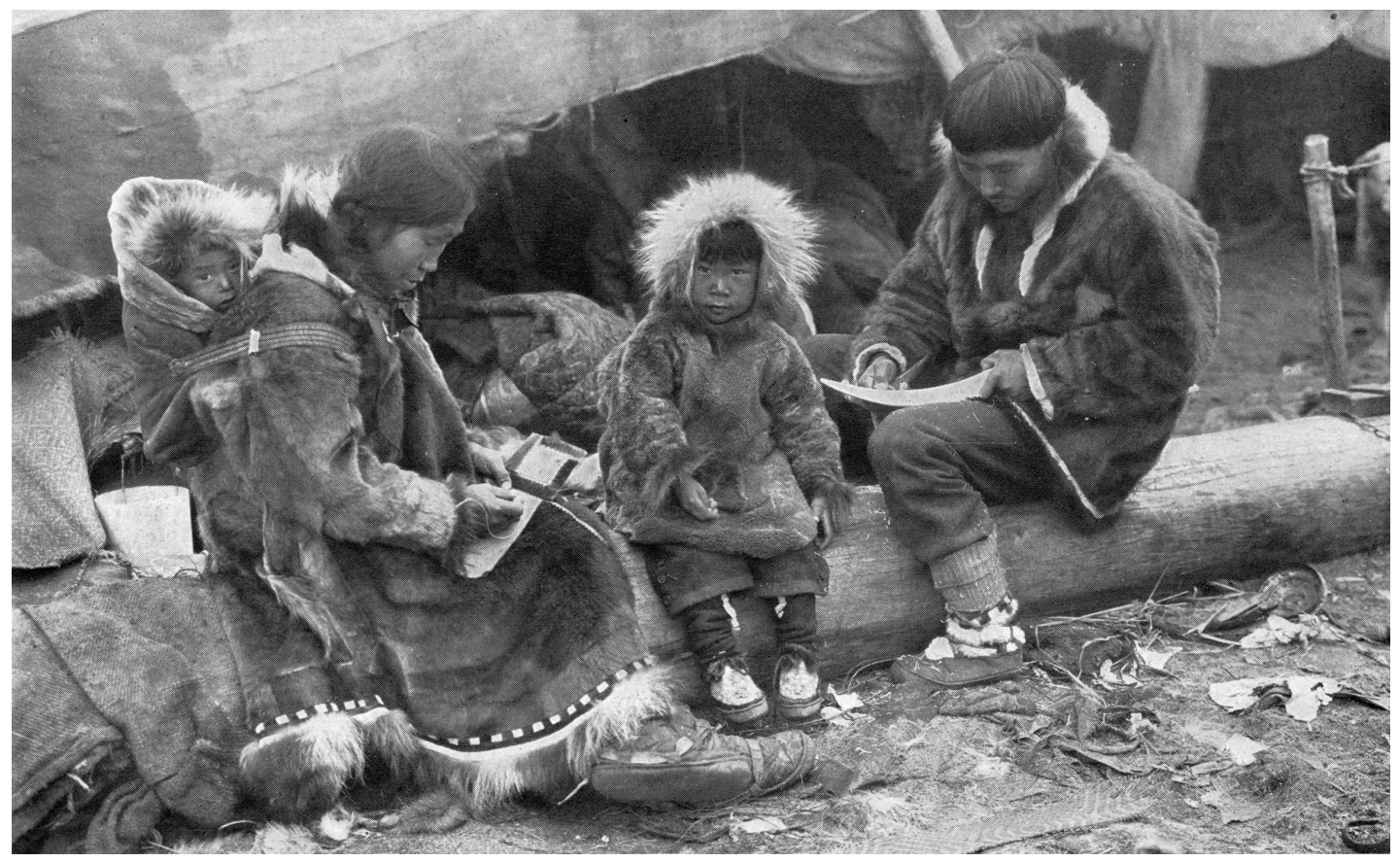

Fig. 1: An Eskimo family

As a producer of exoticism, the photographer, George R. King, illustrates with this picture the construction of otherness with reference to the «noble savage», who is different to Westerners, as supported by its given caption entitled «An Eskimo family. Tenderness and responsibility in their treatment of children is a virtue of the Eskimo which binds them closer to the brotherhood of civilized peoples».

Eine Eskimo-Familie

Famille eskimo

Source: National Geographic Magazine 1917, vol. 31: 564

tion can be defined as one of the cognitive processes by which Europe, and more broadly the West, built schemata of interpretation that organize and frame the world. It gives meaning to it and makes it possible to think and practice it at a global scale. Exoticism is based on a dichotomic and hierarchical opposition between us, here, and the others, elsewhere. It is a generic form of geographical othering, of which Orientalism is the best-known expression. Exoticism is characterized on the one hand by the association of geographical distance and the existence of a symbolical gap, on the other hand by the enhanced value of otherness, seen as charming and attractive. This is paradoxical if one believes in the universal character of ethnocentrism. Exoticisation involves a symbolic and material domestication of the world, a making of the world on a global scale. This allowed the other and elsewhere to be no longer considered threatening, and they subsequently became objects of desire and con- sumption. The exotic is therefore not the characteristic of an object, a place or a human being, but the characteristic of a glance and a discourse (GAUTHIER 2008; STASZAK 2008a). Exoticism belongs to economic, social, political and cultural history. The exoticization process is related to a central place (European colonial countries), a key moment (the end of the 19th century), a founding practice (travel) and specific representations (images, and particularly photographs) (Fig. 1).

The end of exoticism has been often claimed, nevertheless exoticisation is still at work (GAUTHIER 2009). It takes part in the enchantment of the world exploited by international tourism, television broadcasts (i.e. Rendez-vous en terre inconnue in France), and marketing to sell material or immaterial exotic products (presented as «ethnic», «tribal», «of the world»). Some places like Tahiti, Egypt or the Arctic region are of particular interest to members of the department of geog- 
raphy in Geneva, as well as chosen materials (dance, photography, cinema, zoological garden, tourist brochure, postcards, interviews but also scientific texts), specific actors (travellers, tourists, photographs, painters, writers, geographers, movie stars) and practices (tourism, ecotourism, sex tourism, dark tourism: NAEF $2010,2011)$. In the following paragraphs, we demonstrate through two further examples of research projects how the circulation of cognitive frames and material objects serves to construct the globe as global.

Images, both mental and iconographical, play a major role in the way people imagine a place, give meaning and coherence to it, and practice it. The expansion of transport and communication has been accompanied by a spreading of images (as objects) that grounded and allowed globalization, thanks to the spread of new communications media, and amongst it, photography. Images help to give meaning(s) to globalization and to the meet with «others», to mobilize its actors and to guide thoughts and actions. They assign particular functions to specific political, cultural and geographical areas and determine the way people interact. The terms «iconoscape» or «image world» (Poole 1997) helps to analyse this phenomenon as a part of the globalization process and international exchanges. We try to capture social and political relations between image-makers, consumers and areas of imagination. Thus we pay attention to the production, circulation, consumption of images and their relations to political, economical and ideological changes. We study geographical imaginations through actors who participate in this process as creators (GAUTHIER 2011), or buyers or consumers of images for different purposes: commercial (e.g. tourism), political (e.g. colonization), or religious (e.g. missionary propaganda).

In order to understand how such images participate in framing the other, and in constructing the world, Queer Studies and the theory of intersectionality suggest that categories of gender, class and race often interact on simultaneous levels. Strangeness and attractivity of the exotic are often thought of in sexual terms. The indigenous body (male but most of all female) becomes an object of desire as a result of the qualities the colonial culture attributed to it, but also as a result of its actual availability in the balance of power in the colonial situation. From colonial prostitution to sexual tourism (STASZAK 2012), geographical imaginaries and practices are involved in the eroticization of the exotic. Thus the research conducted at the department of geography considers the eroticization of the female body in painting (Paul Gauguin; see STASZAK 2003), photography (i.e. Alfred Bertrand, see GaUthIER 2011), cinema (STASZAK 2011), dance (STASZAK 2008b) and more generally within the Western geographical imagination (Fig. 2).

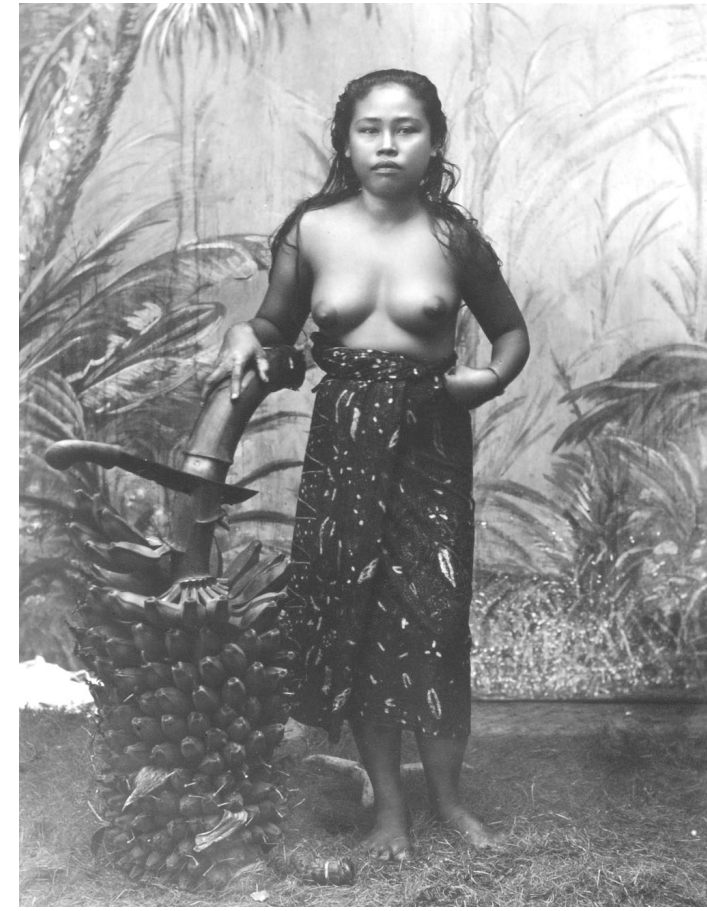

Fig. 2: Girl of the Preanger Java

This photograph displays a woman who is both exoticized and eroticized. Through the choice of background, props, her semi-nudity and her costume, the photographer presents her as both an exotic object and a sex object.

Mädchen der Preanger Java

Fille des Preanger Java

Source: anonymous, before 1880, Geneva Ethnography Museum, Collection Alfred Bertrand, ${ }^{\circ} 412610$ (reprinted with permission)

\section{Example 3: the globalization of environmental and cultural issues}

Another series of research projects undertaken at the department of geography in Geneva (Bernard Debarbieux, Gilles Rudaz, Jörg Balsiger, Mathieu Petite, Cristina Del Biaggio) brings the two topics presented above together: the globalization of the frames of environmental issues and the globalization of the making of otherness. The research context chosen was that of mountain regions and mountain people due to the increased interest in mountain issues at a global level since the Earth Summit in Rio (1992). An intense and efficient lobbying which combined the activism of some Intergovernmental Organisations - IGOs, global Non-Governmental Organisations - NGOs, scientists 
and States such as Bolivia, Italy and Switzerland, has led to the official recognition of mountain regions as a specific priority for sustainable development policies, and the writing of a specific chapter in «Agenda 21» (Rudaz 2011). During this period an intense activity in mapping (i.e. the making by the United Nations Environment Programme - UNEP of the first global map of mountains which is now the reference for defining mountain areas around the world) and publishing has grounded the visual and argumentative framing of the issues (Debarbieux \& Rudaz 2010).

The prominence given to mountains at the global level was renewed in 2002 with the International Year of Mountains - IYM supported by the United Nations and a large number of States. That same year, during the World Summit on Sustainable Development in Johannesburg, the Mountain Partnership was created as a voluntary alliance of interested parties with the common goal of achieving sustainable development around the world. It now has a highly heterogeneous membership comprising 50 countries, 16 intergovernmental organizations, and 112 major groups, with considerable contrasts in their respective ways of framing mountain issues. This wide advocacy coalition and the newly created institutions illustrate a fascinating example of re-scaling of environmental issues: the rise of a global concern for mountains involved stakeholders at various scale-levels, helped to promote national mountain policies, and initiated a large number of transnational, regional and transboundary initiatives, many of them spatially framed at the level of major mountain ranges (e.g. Alps, Carpathians, Himalaya, Central Andes). Therefore globalization definitely appears as the outcome of complex institutional arrangements involving stakeholders at various scalelevels, articulating various framings relative to their respective agendas (DEBARBIEUX 2009).

In this process, a manifest competition took place between stakeholders promoting opposite frames. Among many examples, the case of mountain people's associations is enlightening. The «mountain people» or «mountaineer» category was framed by natural sciences and philosophy since the 18 th century. It was a tool for conceiving a somewhat deterministic relation between natural and social entities. It was instrumentalized by touristic imaginaries and public policies. However, it was only in the middle of the 20th century that this was used directly by the people living in the mountains as a label for self-definition and selfidentification. From that moment on, this designation became a political tool for legitimizing endogenous conceptions of mountain management that was challenged by tourist elites (especially alpine clubs who claimed to bring together the real «mountaineers»), environmental movements and national administra- tions. With the rise of the global concern for mountains since Rio and Johannesburg and the growing activism of IGOs and global NGOs, existing associations of so-called mountain people have been struggling hard again against forms of instrumentalization of their own image (i.e. the one of «mountain women» for example, see Rudaz \& Debarbieux 2011) and a denial of their rights, as well as struggling to get some kind of regional (see Del BIAGgio 2009) or global recognition (Debarbieux 2008). This led to the creation of a World Mountain People Association in 2002 and its admission into the Mountain Partnership.

\section{Conclusion}

These three examples display the close relations which exist between the globalization processes of environmental issues on the one hand, and of the social and political identification of people through the making of cultural difference and the definition of social roles and rights. These processes, which are strongly related to the production of knowledge, images, categories (SCHAFFTER et al. 2010), arguments and narratives, cannot be simply explained by the transfer to the global scale-level of pre-existing processes at lower scale-levels. Rather, they give way to profound rearrangements of geographical entities, social identities, and political competencies for which pre-existing institutional scale-levels are still very much relevant and according to which new levels, such a regional ones (BALSIGer \& Debarbieux 2011), are emerging.

\section{References}

Aberley, D. (ed.) (1993): Boundaries of home: mapping for local empowerment. - Philadelphia: New Society Publishers.

Balsiger, J. \& B. Debarbieux (2011): Regional environmental governance: interdisciplinary perspectives, theoretical issues, comparative designs. - Geneva: Procedia-Elsevier.

BENFORD, R. \& D. SNOw (2000): Framing processes and social movements: an overview and assessment. - In: Annual Review of Sociology 26: 611-639.

Callon, M., Lascoumes, P. \& Y. Barthe (2001): Agir dans un monde incertain. Essai sur la démocratie technique. - Paris: Editions du Seuil.

Debarbieux, B. (2008): Le montagnard: imaginaires de la territorialité et invention d'un type humain. - In: Annales de Géographie 660: 90-115.

Debarbieux, B. (ed.) (2009): Mountain regions as referents for collective action. - Journal of Alpine Research 97, 2.

Debarbieux, B. \& G. Rudaz (2010): Les faiseurs de montagne. - Paris: CNRS Editions.

Del Biaggio, C. (2009): The institutionalization of the 
alpine region: an analysis based on a study of two panalpine networks (Alliance in the Alps and Alparc).Revue de géographie alpine 97,2.

Delanay, D. \& H. Leitner (1997): The political construction of scale. - In: Political Geography 16, 2: 93-97. FALL, J.J. (2010): Grounding politics on nearness? - In: Geographische Zeitschrift 98, 4:213-225.

FALL, J.J. (2011a): Dolori della crescita: quando le erbacce invadono il giardino. - Bollettino della Società Geografica Italiana, Serie XIII, vol. IV: 785-799.

FALL, J.J. (2011b): Natural resources and transnational governance. - In: WastL-Walter, D. (ed.): The Ashgate research companion to border studies. - Ashgate: Aldershot: 627-642.

FALL, J.J. (2012): Invasions étranges, invasions étrangères, ou quand cygnes et écureuils bouleversent les frontières. - In: Dubied, A., Gerber, D. \& J.J. FAll (eds): Aux frontières de l'animal: mises en scènes et reflexivités. - Collection Travaux de sciences sociales, Genève, Paris: Droz: 177-188.

Fall, J.J. \& L. Matthey (2011): De plantes dignes et d'invasions barbares: les societies au miroir du vegetal. - In: Vertigo: Revue électronique en sciences de l'environnement (manuscript accepted).

FARINELLI, F. (2009): De la raison cartographique. Paris: Comité des travaux historiques et scientifiques - CTHS.

Faure, A., Pollet, G. \& P. Warin (eds) (1997): La construction du sens dans les politiques publiques. Débats autour de la notion de référentiel. - Paris: L'Harmattan.

GauthiER, L. (2008): L'Occident peut-il être exotique? De la possibilité d'un exotisme inversé. - In: Le Globe 148: 47-64.

Gauthier, L. (2009): Jemaa el-Fna ou l'exotisme durable. - In: Géographie et Cultures 72:117-136.

Gauthier, L. (2011): Femmes orientales et photographes commerciaux. La construction d'un imaginaire dans la production photographique des années 18601880. - Cybergeo: European Journal of Geography.

Goffman, E. (1974): Frame analysis: an essay on the organization of experience. - London: Harper and Row.

KurTz, H.E. (2003): Scale frames and counter-scale frames: constructing the problem of environmental injustice. - Political Geography 22, 8: 887-916.

LARSEN, H.G. (2008): Scaling the Baltic Sea environment. - In: Geoforum 39, 6: 2000-2008.

Marston, S.A. (2000): The social construction of scale. - In: Progress in Human Geography 24, 2: 219-242.

Moore, A. (2008): Rethinking scale as a geographical category: from analysis to practice. - In: Progress in Human Geography 32, 2: 203-225.

NAEF, P. (2010): Mise en tourisme et production patrimoniale au Monténégro: Kotor et sa «labélisation UNESCO». - In: Géo-Regards 3: 89-103.

NAEF, P. (2011): Du traumascape au touristscape:
Regards croisés sur Vukovar et Sarajevo. - In: TSANTSA - Revue de la Société Suisse d'Ethnologie 16:164-169.

PickLes, J. (2004): A history of spaces: cartographic reason, mapping and the Geo-coded world. - London: Routledge.

Poole, D. (1997): Vision, race and modernity. A visual economy of the Andean image world. - Princeton, N.J.: Princeton University Press.

Rudaz, G. (2011): The cause of mountains: the politics of promoting a global agenda. - In: Global Environment Politics 11, 4: 43-65.

Rudaz, G. \& B. Debarbieux (2011): «Mountain women»: silent contributors to the global agenda for sustainable mountain development. - In: Gender, Place and Culture (forthcoming).

Schaffter, M., Fall, J. \& B. Debarbieux (2010): Unbounded boundary studies and collapsed categories: rethinking spatial objects. - In: Progress in Human Geography 34, 2: 254-262.

SNow, D.A. \& R.D. Benford (1988): Ideology, frame, resonance and participant mobilization. - In: International Social Movements Research 1,1:197-217.

StASZAK, J.-F. (2003): Géographies de Gauguin. - Paris: Bréal.

Staszak, J.-F. (sous la direction de) (2008a): L'exotisme. - Le Globe 148.

StaSzaK, J.-F. (2008b): Danse exotique, danse érotique. Perspectives géographiques sur la mise en scène du corps de l'Autre (XVIIIe-XXIe siècles). - In: Annales de géographie 660-661, mai-juin: 129-158.

Staszak, J.-F. (2009): Other/otherness. - In: Thrift, N. \& R. Kitchin (dir.): International encyclopedia of human geography. - Amsterdam: Elsevier.

STASZAK, J.-F. (2011): La fabrique cinématographique de l'altérité. Anna May Wong et les personnages de «Chinoises» dans le cinéma occidental (1919-1940). In: Annales de géographie 682, 6: 577-603.

STASZAK, J.-F. (2012): L'imaginaire géographique du tourisme sexuel. - In: L'Information géographique (forthcoming).

\section{Summary: Framing globalization and constructing the world: cultural and political approaches}

This paper discusses the extent to which globalization can be analysed also as a cognitive process that relies on the emergence of new key figures and representations, as well as new meanings and new forms of circulation that are associated with them. In order to link up different fields of geographical research spanning cultural and political geographies and to foster a theoretically-informed critical geography, this paper explores how the joint concepts of «scaling» and «framing» can create pathways and connections across the usual sub-discipline divisions that can be found in much so-called international geography. It explores 
this approach theoretically, before applying it to three examples currently considered within existing research projects: the globalization and rescaling of environmental discourse; the circulation of images of otherness and process of othering; and the globalization of environmental and cultural issues within mountain regions.

Keywords: environment, globalization, framing, mountain regions, othering, scale

\section{Résumé: Donner un cadre à la mondialisation et construire le monde: approches culturelles et poli- tiques}

Dans quelle mesure la mondialisation peut-elle être aussi analysée comme un processus cognitif, fondé sur l'émergence et la circulation de nouvelles représentations? Pour répondre à cette question, il est nécessaire de mettre en rapport plusieurs champs de recherche en géographie, en particulier de décloisonner la géographie politique et la géographie culturelle, et de tenter de théoriser une géographie critique. Cet article suggère de le faire autour des concepts liés d'échelle et de cadrage, qui conduisent à dépasser la division de la géographie en sous-disciplines. La première partie de l'article explore ces pistes sur un plan théorique. La seconde l'applique à trois exemples, qui correspondent à autant de programmes de recherche: la mondialisation et les changements d'échelle des discours environnementalistes, la circulation des images de l'autre et les processus d'exotisation, les enjeux environnementaux et culturels de la mondialisation dans les zones de montagne.

Mots-clés: environnement, exotisation, cadrage, échelle, mondialisation, montagne

\section{Zusammenfassung: Globalisierung und Konstruktion der Welt: kulturelle und politische Ansätze}

Dieser Beitrag diskutiert das Ausmass, in welchem Globalisierung auch als ein kognitiver Prozess analysiert werden kann, der auf der Entstehung von neuen Schlüsselfiguren sowie neuen Bedeutungen und
Formen der Zirkulation, die damit verbunden sind, beruht. Um verschiedene Felder geographischer Forschung zu verbinden, die Kultur- und Politische Geographie umspannen, und um eine theoretisch-informierte Kritische Geographie zu fördern, untersucht dieser Beitrag, wie die gemeinsamen Konzepte von «scaling» und «framing» Wege und Verbindungen über die gewohnten subdisziplinären Einteilungen hinaus kreieren können, welche in der sogenannten Internationalen Geographie gefunden werden können. Der Beitrag untersucht diesen Zugang theoretisch, bevor er auf drei Beispiele angewandt wird, die gegenwärtig innerhalb aktueller Forschungsprojekte betrachtet werden: die Globalisierung und die Veränderungen des Massstabes in Umwelt-Diskursen, die Zirkulation von Bildern des Anderen und der Prozesse der Exotisierung sowie die Globalisierung von Umwelt- und kulturellen Sachverhalten in Berggebieten.

Schlüsselwörter: Umwelt, Globalisierung, «framing», Berg, Exotisierung, Massstab

Prof. Dr. Bernard Debarbieux, Prof. Dr. Juliet J. Fall, Prof. Dr. Frédéric Giraut, Dr. Estelle Sohier, Prof. Dr. Jean-François Staszak, Département de Géographie, Université de Genève, 40 Bd du Pont-d'Arve, CH-1211 Genève 4, Switzerland.

e-mail:

Bernard.Debarbieux@unige.ch

Juliet.Fall@unige.ch

Frederic.Giraut@unige.ch

Estelle.Sohier@unige.ch

Jean-Francois.Staszak@unige.ch

\section{Manuskripteingang/received/manuscrit reçu le} 1.9.2011

Annahme zum Druck/accepted for publication/accepté pour publication: 17.4 .2012 